\title{
VirSbud: Key Characteristics, Applications, and its Future
}

https://doi.org/10.3991/ijim.v11i6.6926

\author{
Radzuwan Ab Rashid( $\left.{ }^{\varpi}\right)$, Saiful Bahri Mohamed \\ Universiti Sultan Zainal Abidin, Kuala Terengganu, Terengganu, Malaysia \\ radzuwanrashideunisza.edu.my \\ Mohd Fazry A. Rahman \\ Shah Alam Community College, Shah Alam, Selangor, Malaysia \\ Syadiah Nor Wan Shamsuddin \\ Universiti Sultan Zainal Abidin, Kuala Terengganu, Terengganu, Malaysia
}

\begin{abstract}
Learning a second language is not an easy task. Learners need to have enough support in terms of learning materials in order to be successful in mastering the language. One of the common problems faced by the second language learners is the difficulty to find the learning materials to develop their speaking skills. This is in contrast to the materials for the development of other language skills, such as reading and writing which are easily accessible from bookstores and resource centers. This paper introduces an innovative application named Virtual Speaking Buddy (VirSbud) which is specially designed to help second language learners develop their speaking skills. It is hoped that this application will be a useful resource to improve the standard of speaking skills among English language learners.
\end{abstract}

Keywords-Educational application, English language learning, speaking skills, VirSbud.

\section{$1 \quad$ Introduction}

VirSbud stands for Virtual Speaking Buddy. It is an innovative application that is designed to aid young learners in learning to speak English and develop their confidence to use the language, which is the official second language in Malaysia. Similar to other second language users of English worldwide, many Malaysian users have problems to master speaking skills despite their ability to read and write well in the language [1],[2],[3],[4], [5]. This is perhaps due to the emphasis given in schools where reading and writing are given extra attentions by the teachers compared to the listening and speaking. In Malaysia, reading and writing are the two language skills tested in examinations for primary and secondary schools whilst listening and speaking are only tested when the learners sit for Malaysian University English Test (MUET) when they further their tertiary education [6]. Because of the lack of empha- 
sis on these two skills, resources to develop the skills are very limited. VirSbud application is designed to address this problem so that learners are accessible to interactive application in order to develop their speaking skills.

The first version of VirSbud has been tested with a group of primary school students and based on the users' feedback, its revised version is currently being developed. This paper aims to share the key characteristics of this application, how it can be used as a tool for the second language learners to develop their speaking skills, and its future development plan.

\section{Key Characteristics}

VirSbud is designed based on two interrelated concepts: Fun Learning and Autonomous Learning. Based on the fun learning concept, VirSbud is designed to be appealing to young learners by having an animation as its main character, as shown in Fig. 1.

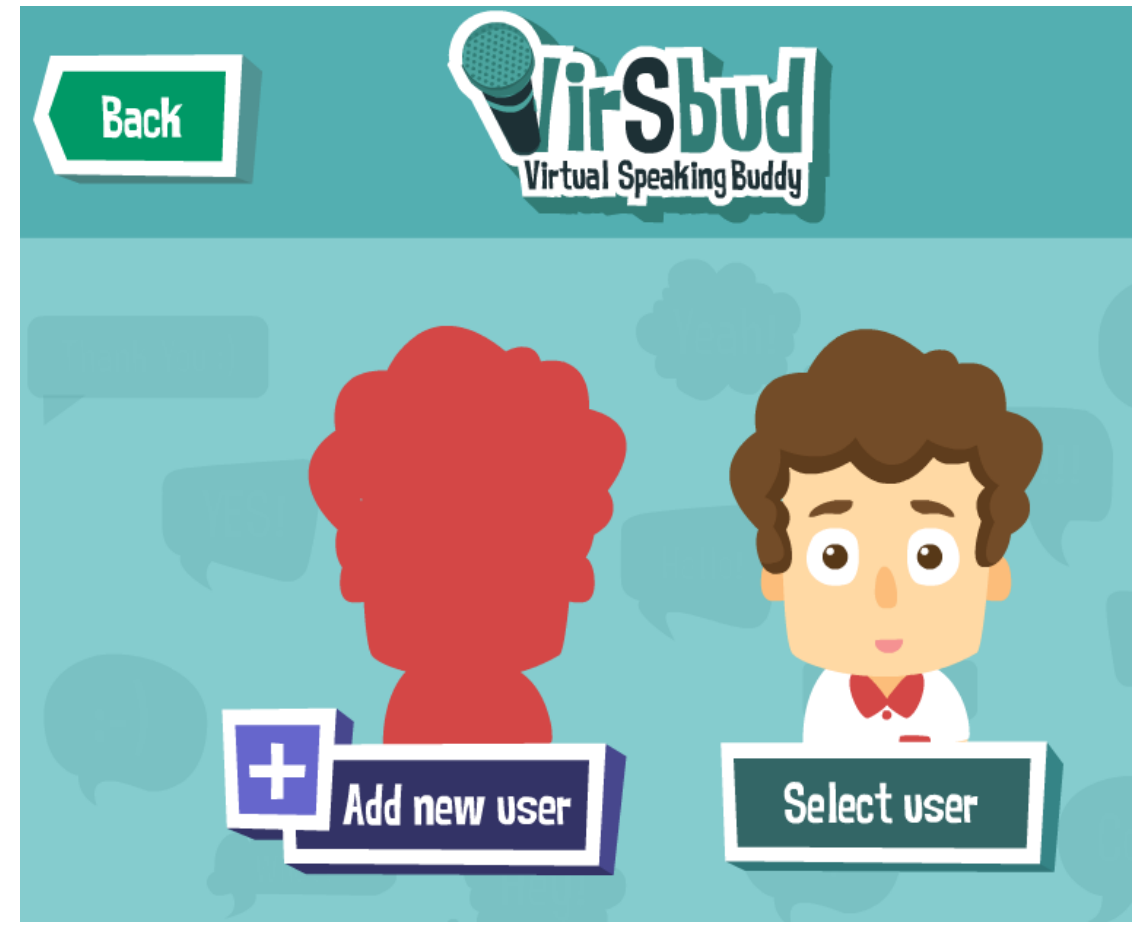

Fig. 1. The animation in VirSbud

The animation serves as the virtual speaking buddy to the learners. This speaking buddy invites the learners to speak to him by asking several questions to the learners. The questions are arranged according to three level of difficulties: beginner, intermediate and advanced. An example of question for intermediate level is shown in Fig. 2. 
This application is made interactive by having the virtual speaking buddy asking follow up questions to the learners. The follow up questions are smartly designed so that they are responsive to the answers of the earlier questions given by the learners. This is done by designing the follow up questions as broad as possible but within the scope of the earlier questions. An example of the follow up question to the question shown in Fig. 2 is shown in Fig.3.

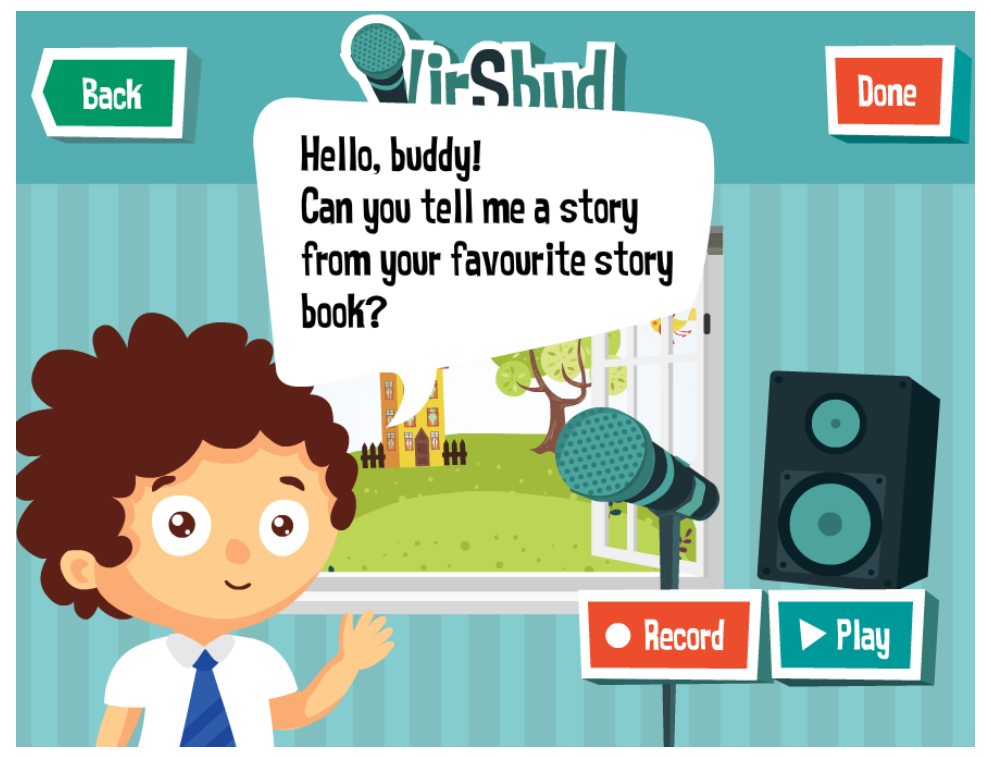

Fig. 2. An example of question of intermediate level

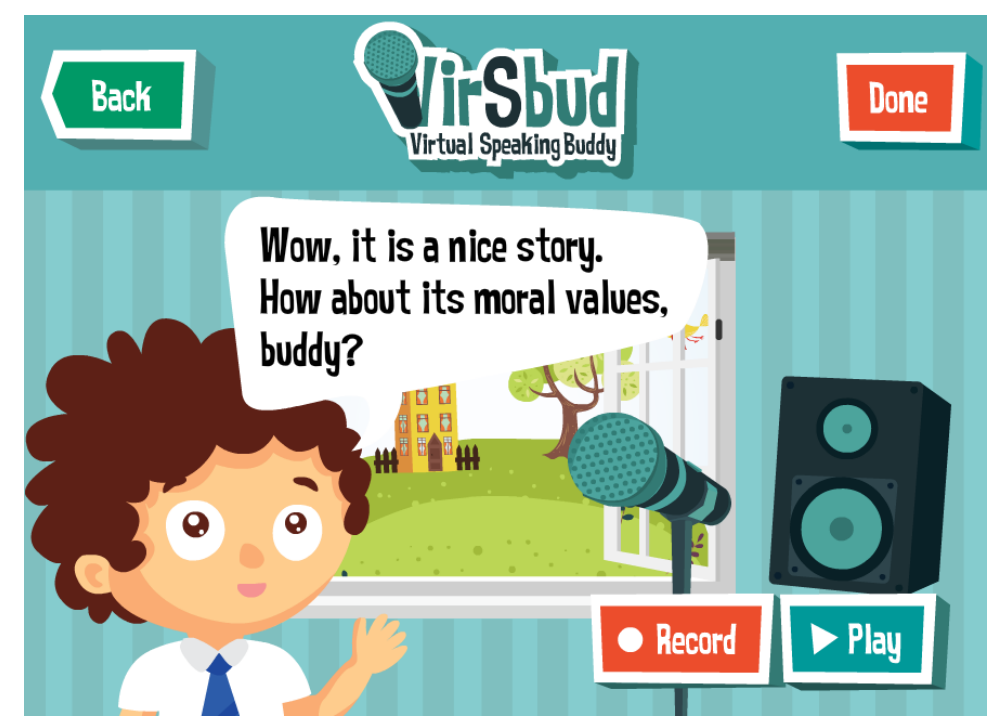

Fig. 3. An example of follow up question designed for interactivity 


\section{$3 \quad$ Application of VirSbud in Teaching and Learning}

Virsbud can be integrated in teaching and learning in several ways. Firstly, the teachers can use the application as a teaching material in the classroom as the prompts in VirSbud are designed based on text book syllabus. It can be used for 'Set Induction' stage to stir the learners' interest in learning the topic of the day, 'While Speaking' activities for students to complete the speaking task or the 'Post-Production' stage as an enrichment to what have been taught.

Secondly, the learners can be assigned to use VirSbud as a homework as learners can easily access the application through their computer regardless of their geographical distribution. This is another interesting characteristic of VirSbud that it can be accessed at anytime and anywhere thus encouraging the autonomous learning. Upon the completion of the homework, the learners can show the recorded conversation with their speaking buddy to their teacher for feedback.

In addition, the learners can use the application as an informal learning tool without the teachers' presence. This is because the recorded version can be accessed by any 'more-knowledgeable others', such as parents, brothers, or friends who can give them feedback on their recorded conversation. This is very useful as some students are too shy to show the recorded conversation to their teachers. As mentioned by some of our participants when we tested the application, they learn from the parents and brothers' feedback as much as they learn from the teachers' feedback. In other words, VirSbud encourages the 'social learning' [7] to occur. Some other participants use the opportunity to show the recorded conversation to parents when they are practicing the conversation. This lack of dependency to teachers is good as it reduces the teachers' workload. As mentioned by [8], teachers in Malaysia mostly suffer from the heavy workload. It is only when they have satisfied with the conversation that they show the recording to the teachers who can then give marks to them, as shown in Fig.4 below.

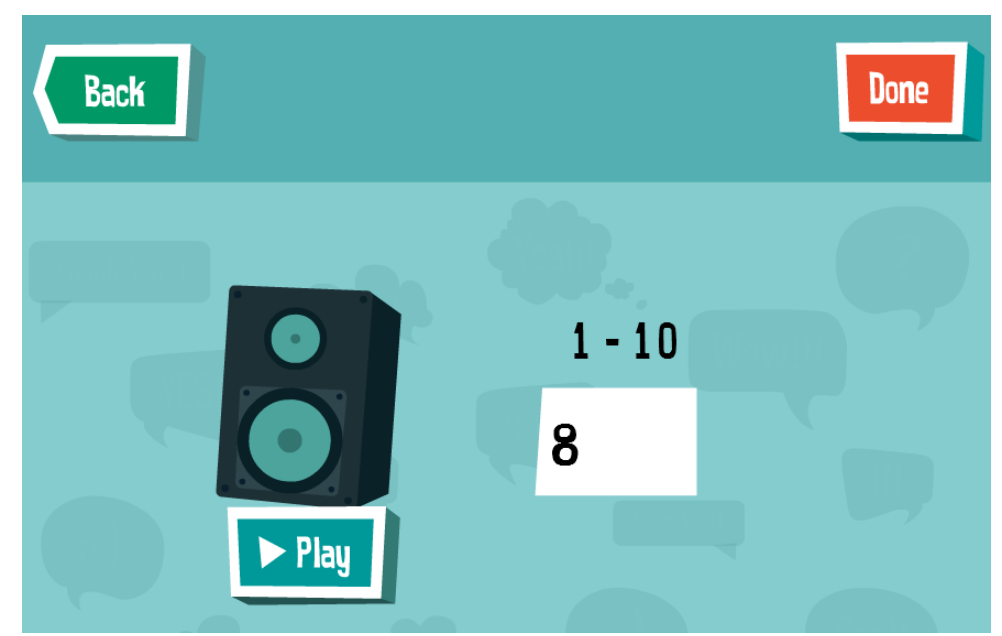

Fig. 4. An example of scoring by the teacher 


\section{The Future of VirSbud}

In its current form, VirSbud has won several awards at international innovation competitions. This includes a gold medal at Innovation and Invention Competition through Exhibition 2016 (iCOMPEX'16), a silver award at International University Carnival on eLearning (IUCEL) 2016, and the main prize (Diamond Award) at International Invention and Innovative Competition (InIIC) 2/2016. These competitions, even though held in Malaysia, were participated by innovators from several countries including Thailand, Singapore, and Indonesia.

Based on the feedback given by the judges, VirSbud is going to be further developed. It is in the process to be transformed into a language learning hub where users of this application will have the opportunity to learn five different languages including Arabic, Malay language, English, Korean, and Mandarin. The addition of these languages are hoped to attract more users as the languages are popular among the young learners besides being useful in their daily lives.

\section{$5 \quad$ Acknowledgment}

This project is funded by Universiti Sultan Zainal Abidin (UniSZA), Malaysia, under the DPU Research Grant UniSZA/2016/DPU/03.

\section{$6 \quad$ References}

[1] Rashid, R.A. (2011). Vocabulary learning among young adults using children's stories. Mextesol, 35(1): 1-11.

[2] Ismail, A., \& Yusof, N. (2016). Readability of ESL picture books in Malaysia. Journal of Nusantara Studies, 1(1): 60-70.

[3] Rashid, R.A., Vethamani, M.E. \& Shireena, B. (2010). Approaches employed by teachers in teaching literature to less proficient students in Form 1 and Form 2. English Language Teaching, 3(4): 87-99. https://doi.org/10.5539/elt.v3n4p87

[4] Yunus, K., Mohamad, M., \& Waelateh, B. (2016). The breadth of receptive vocabulary knowledge among English major university students. Journal of Nusantara Studies, 1(1): 7-17.

[5] Mihat, W. (2016). 'Bertehtuh' English: The experience of a Temiar girl in acquiring English. Journal of Nusantara Studies, 1(2): 25-37.

[6] Albury, N.J. \& Aye, K. K. (2016). Malaysia's national language policy in international theoretical context. Journal of Nusantara Studies, 1(1): 71-84.

[7] Vygotsky, L.S. (1978) Interaction between learning and development. In: Cole, M., JohnSteiner, V., Scribner, S. and Souberman, E. (Eds.) Mind in society: the development of higher psychological processes, pp.79-91. Cambridge, MA: Havard University Press.

[8] Rashid, R.A., Rahman, M.F.A., \& Rahman, S.B.A. (2016). Teachers' engagement in social support process on a networking site. Journal of Nusantara Studies, 1(1): 34-45 


\section{$7 \quad$ Authors}

Dr Radzuwan Ab Rashid is the Deputy Dean of Research and Innovation at Faculty of Languages and Communication, Universiti Sultan Zainal Abidin, Malaysia.

Associate Professor Dr. Saiful Bahri Mohamed is the Director of Research Management, Innovation, and Commercialisation Centre (RMIC), UniSZA

Mohd Fazry A. Rahman is a lecturer at Shah Alam Community College, Malaysia.

Dr Syadiah Nor is currently the Dean of Faculty of Informatics and Computing, University Sultan Zainal Abidin, Malaysia.

Article submitted 20 March 2017. Published as resubmitted by the authors 13 May 2017. 